\title{
From a metagenomic source to a high-resolution structure of a novel alkaline esterase
}

\author{
Mariana Rangel Pereira ${ }^{1,2,3}$ - Thaís Carvalho Maester ${ }^{2,3}$. \\ Gustavo Fernando Mercaldi ${ }^{1,4}$. Eliana Gertrudes de Macedo Lemos ${ }^{3}$. \\ Marko Hyvönen ${ }^{5}$ - Andrea Balan ${ }^{6}$
}

Received: 31 July 2016/Revised: 27 February 2017 / Accepted: 5 March 2017 /Published online: 22 March 2017

(C) Springer-Verlag Berlin Heidelberg 2017

\begin{abstract}
Esterases catalyze the cleavage and formation of ester bonds and are members of the diverse family of $\alpha / \beta$ hydrolase fold. They are useful in industries from different sectors, such as food, detergent, fine chemicals, and biofuel production. In a previous work, 30 positive clones for lipolytic activity were identified from a metagenomic library of a microbial consortium specialized in diesel oil degradation. In this study, a putative gene encoding an esterase/lipase, denominated est 8 , has been cloned and the corresponding protein expressed recombinantly, purified to homogeneity and characterized functional and structurally. We show that the protein codified by est 8 gene, denominated Est8, is an alkaline esterase with high catalytic efficiency against $p$ nitrophenyl acetate and stable in the presence of up to $10 \%$ dimethyl sulfoxide. The three-dimensional structure of Est8 was determined at 1.85 - Á resolution, allowing the
\end{abstract}

Electronic supplementary material The online version of this article (doi:10.1007/s00253-017-8226-4) contains supplementary material, which is available to authorized users.

Andrea Balan

abalan@usp.br

1 National Laboratory of Biosciences (LNBio), Brazilian Center for Research in Energy and Materials (CNPEM), Campinas, São Paulo State, Brazil

2 University of São Paulo (USP), São Paulo, São Paulo State, Brazil

3 Department of Technology, São Paulo State University (UNESP), Jaboticabal, São Paulo State, Brazil

4 Institute of Biology, University of Campinas, Campinas, São Paulo State, Brazil

5 Department of Biochemistry, University of Cambridge, Cambridge, UK

6 Department of Microbiology, Institute of Biomedical Sciences, University of São Paulo, São Paulo, Brazil characterization of the substrate-binding pocket and features that rationalize the preference of Est 8 for short-chain substrates. In an attempt to increase the size of ligand-binding pocket and enzyme activity against distinct substrates of long chain, we mutated two residues ( $\mathrm{Met}^{213}$ and $\mathrm{Phe}^{217}$ ) that block the substrate channel. A small increase in the reaction velocity for $p$-nitrophenyl butyrate and $p$-nitrophenyl valerate hydrolysis was observed. Activity against $p$-nitrophenyl acetate was reduced. The functional and structural characterization of Est8 is explored in comparison with orthologues.

Keywords Esterase $\cdot$ Metagenomic $\cdot$ Structure $\cdot$ Est $8 \cdot p$-NP esters

\section{Introduction}

Lipolytic enzymes are among the most useful biocatalysts with high potential to be employed in various industrial applications such as production of pure compounds (Lorenz and Eck 2005; Quax and Brokhuizen 1994), food processing (Giuliani et al. 2001; Choi and Lee 2001), paper (Kontkanen et al. 2004), and detergent manufacturing (Jaeger and Reetz 1998). These enzymes are widely distributed in animals, plants, and microorganisms and are classified according to their substrate preference as either esterases (E.C.3.1.1.1) or lipases (E.C.3.1.1.3), both of which catalyze the hydrolysis and synthesis of fatty acid esters (Arpigny and Jaeger 1999).

Esterases and lipases are members of a diverse family of $\alpha / \beta$ hydrolases (Nardini and Dijkstra 1999) that have diverged from a common ancestor preserving the arrangement of the catalytic residues but not the binding site as a whole (Ollis et al. 1992). Esterases can be differentiated from lipases by the nature of their preferred substrates and interfacial activation, substrate hydrophobicity, enantioselectivity, and 
solvent stability (Bornscheuer 2002). Bacterial lipolytic enzymes have been traditionally classified into eight families based on their biological properties and conserved sequence motifs (Arpigny and Jaeger 1999), but new families have recently been proposed (Lee et al. 2006; Kim et al. 2009; Rao et al. 2013).

Several lipolytic enzymes from family IV have been isolated from different environments through metagenomic approach (JunGang et al. 2010; Jeon et al. 2012; Jin et al. 2012; Peng et al. 2014). However, just a few of them have been functionally and structurally characterized (Byun et al. 2007; Nam et al. 2009; Ngo et al. 2013). In a previous publication (Pereira et al. 2015), we identified the PL17.E10 fosmid clone from a metagenomic library of a microbial consortium specialized for diesel oil degradation (Paixão et al. 2010), which showed strong lipolytic activity on agar Petri dishes containing tributyrin. The DNA of PL17.E10 was subcloned, sequenced, and annotated. Four open reading frames (ORFs) were identified encoding putative $\alpha / \beta$ hydrolases, which may be responsible for the lipolytic activity. In addition, we showed that Est16 is one of these proteins, which belongs to family V of bacterial lipolytic enzymes, and it is active against a broad range of substrates with short and long acyl chains, mainly $p$-nitrophenyl butyrate $\left(\mathrm{C}_{4}\right)$ and $p$-nitrophenyl valerate $\left(C_{5}\right)$ (Pereira et al. 2015). Similarly, Est3 was isolated from the same metagenomic library, belonging to family IV. It exhibited activity against $\mathrm{C}_{4}, \mathrm{C}_{5}$, and $\mathrm{C}_{8}$ (Maester et al. 2016).

Following the identification of new enzymes with biotechnological application potential, this work shows that Est8 is another member of family IV of bacterial lipolytic enzymes sharing structural similarities with the highly thermostable esterase from Pyrobaculum calidifontis (PDB ID 2YH2) (Palm et al. 2011) but has preferential activity against short-chain substrates. The three-dimensional structure of the protein was solved by crystallography and compared with other esterases in terms of residues from the ligand-binding site, catalytic activity, and characteristics of internal cavity. We discuss key features required for enzyme selectivity and activity.

\section{Material and methods}

\section{Screening for lipolytic activity}

As described in a previous work (Pereira et al. 2015), a fosmid metagenomic library isolated from a microbial consortium specialized in diesel oil degradation was screened for potential esterases/lipases. Positive clones were selected based on their ability to hydrolyze tributyrin in Luria-Bertani (LB) agar Petri dishes evidenced by the formation of a clear halo around the colony. Positive clones were subcloned and their sequences were analyzed to identify putative esterases.

\section{Sequence analysis of $e s t 8$ gene}

Amino acid sequence of Est8 was used as a query sequence in a BLAST search at the National Center for Biotechnology Information (NCBI, Bethesda, Maryland, USA) for identification of orthologous proteins. Representative sequences belonging to eight families of bacterial lipolytic enzymes, as proposed by Arpigny and Jaeger (1999), and also proteins for which three-dimensional structures were available in the Protein Data Bank (PDB) were selected from the results of the BLAST search. A multiple sequence alignment was constructed in ClustalW algorithm (Thompson et al. 1994) in the BioEdit Sequence Alignment Program (version 7.0.5.3) using pairwise alignment with gap opening 35.00 and extension 0.75 and multiple alignments with gap opening 15.00 and extension 0.30 . The alignment file was submitted to $\mathrm{Mr}$. Bayes 3.2 (Ronquist et al. 2012) and MEGA 6.0 (Tamura et al. 2013) to estimate a suitable evolutionary model for phylogenetic tree construction. The tree was constructed using maximum likelihood method with a bootstrap of 1000 replicates and the Whelan and Goldman (WAG) matrix of amino acid substitution. Information of all sequences used in the alignment and phylogenetic tree are shown in Table S1 (Supplementary Information).

\section{DNA amplification and plasmid construction}

A DNA fragment of 936 base pairs containing the est 8 gene (GenBank accession no. KP699699) corresponding to entire 311 amino acid coding region was amplified by PCR from the positive clone P117.E10. The forward (5' CGCGGAAT TCACAATGGCACTCGATC $\left.3^{\prime}\right)$ and reverse (5' CGGGAAGCTTCCTCACGCCAGCGCC 3') oligonucleotides were used for the fragment amplification and insertion of the EcoRI and HindIII restriction enzymes sites (underlined), respectively, in the start and final of the gene. The PCR product was directly cloned into pET28a plasmid (Novagen, Gibbstown, NJ, USA) to generate the pET28a-est8 vector. The expressed protein from this construct presented a $\mathrm{N}$-terminal His-tagged for further purification, confirmed by DNA sequencing analysis. In order to open the substrate channel in Est8, we also amplified est8 gene containing two point mutations in the Met213 and Phe217, which were replaced by Val and Gly, respectively. The mutagenesis was performed using two overlapping oligonucleotides (5' GACGGCGT GATCTGGTTCGGCGATC 3' and 5' GATCGCCG AACCAGATCACGCCGTC $3^{\prime}$ ) that introduced the mutations in two steps of PCR reaction. Terminal oligonucleotides for final amplification (5' TATATCCATGGCACT CGATCCGCAGGCAAAAG $3^{\prime}$ and 5' TATATAAG CTTACGCCAGCGCCTCTTTCAGCGCCTTC 3') introduced restriction sites for $\mathrm{NcoI}$ and HindIII, respectively (underlined). The mutated sequence was cloned into pHAT2 
vector (Peränen et al. 1996), producing pHAT2-est8mf plasmid. The mutated protein is called Est8MF.

\section{Protein expression, extraction, and purification}

The recombinant plasmids were transformed into chemically competent Escherichia coli BL21(DE3) cells for overexpression. The transformed cells were grown in LB media containing kanamycin $\left(50 \mu \mathrm{g} \mathrm{mL}^{-1}\right)$ or ampicillin $\left(100 \mu \mathrm{g} \mathrm{mL}^{-1}\right)$ and agitated at $200 \mathrm{rpm}$ at $37^{\circ} \mathrm{C}$ until $\mathrm{OD}_{600}$ reached 0.5-0.6. Expressions of Est8 and Est8MF proteins were induced with $0.4 \mathrm{mM}$ isopropyl $\beta$-D-1-thiogalactopyranoside (IPTG) from E. coli BL21 (DE3) cells, respectively, carrying pET28a-est8 and pHAT2-est $8 m f$ vectors, and grown for further $18 \mathrm{~h}$ at $20^{\circ} \mathrm{C}$. After this, the cultures were centrifuged at $8000 \mathrm{~g}$ for $10 \mathrm{~min}$ at $4{ }^{\circ} \mathrm{C}$. The cells were resuspended in $30 \mathrm{~mL}$ of $50 \mathrm{mM}$ Tris- $\mathrm{HCl} \mathrm{pH} 8.0$ and lysed with Emulsiflex C5 homogenizer (Avestin Inc., Canada). The cell lysates were adjusted to $500 \mathrm{mM} \mathrm{NaCl}, 10 \mathrm{mM}$ imidazole, $10 \mathrm{mM}(v / v)$ $\beta$-mercaptoethanol, and $10 \%(v / v)$ glycerol and centrifuged at $17,000 \mathrm{~g}$ for $45 \mathrm{~min}$ at $4{ }^{\circ} \mathrm{C}$ to pellet the cell debris. The soluble fractions of the cell lysates were purified using immobilized metal ion chromatography with Ni-NTA resin. An imidazole gradient using the buffer $50 \mathrm{mM}$ Tris- $\mathrm{HCl} \mathrm{pH}$ $8.0,500 \mathrm{mM} \mathrm{NaCl}$, and $10 \%(v / v)$ glycerol was performed. Bound proteins were eluted in the same buffer containing $200 \mathrm{mM}$ imidazole. Peak fractions were pooled, concentrated, and further purified using size exclusion chromatography (SEC) in a Superdex 200 HiLoad 16/60 column (GE Healthcare Bio-Sciences, Uppsala, Sweden) at room temperature in $20 \mathrm{mM}$ Tris- $\mathrm{HCl} \mathrm{pH} \mathrm{8.0,} 200 \mathrm{mM} \mathrm{NaCl}$, and 5\% $(v / v)$ glycerol. The purified fractions of Est8 and Est8MF were analyzed by SDS-PAGE under denaturing conditions, concentrated, and stored at $-80{ }^{\circ} \mathrm{C}$.

\section{Circular dichroism and spectroscopic analysis}

To evaluate the stability of Est8 and Est8MF in different $\mathrm{pH}$, we monitored the secondary structure content and the tryptophan environment using circular dichroism (CD) and intrinsic tryptophan fluorescence. Far-UV CD spectra were recorded on a Jasco-810 spectropolarimeter using a PFD 425S Peltier system for temperature control. Both Est8 and Est8MF proteins were prepared at the final concentration of $5.5 \mu \mathrm{mol}$ in two different buffers, which are $5 \mathrm{mM}$ sodium phosphate $\mathrm{pH}$ 7.0 and $5 \mathrm{mM} \mathrm{N}$-cyclohexyl-2-aminoethanesulfonic (CHES) $\mathrm{pH}$ 9.0. For Est8MF, a CD spectrum was obtained in presence of $11 \mu \mathrm{mol}$ of substrates $p$-nitrophenyl acetate $\left(\mathrm{C}_{2}\right)$ or $p$ nitrophenyl butyrate $\left(\mathrm{C}_{4}\right)$. All measurements were acquired at $10{ }^{\circ} \mathrm{C}$ using a $1-\mathrm{mm}$ path length cell at $0.5-\mathrm{nm}$ intervals over the wavelength range from 195 to $260 \mathrm{~nm}$. The ellipticity was reported as the mean residual ellipticity $[\theta]_{\mathrm{MR}}$ (deg $\mathrm{cm}^{2} \mathrm{dmol}^{-1}$ ). Samples were also subjected to thermal unfolding from 20 to $110{ }^{\circ} \mathrm{C}$ with spectra collected at $1{ }^{\circ} \mathrm{C}$ intervals. The loss of secondary structure was examined by measuring the ellipticity at $222 \mathrm{~nm}$. The $T_{m}$ represents the temperature at the midpoint of the unfolding transition. All data collected were corrected for the buffer baseline contribution.

The fluorescence experiment of Est8 was performed at room temperature in $\mathrm{K} 2$ multifrequency cross-correlation phase and modulation fluorometer (ISS Inc., Champaign, IL, USA). Of the Est8, $1 \mu \mathrm{M}$ was diluted in $5 \mathrm{mM}$ Tris- $\mathrm{HCl}$ buffered at $\mathrm{pH}$ 7.0, 8.0, and 9.0. Assays using tributyrin as substrate were based on the stoichiometry of $1: 2$ (protein:ligand), and samples were incubated for $30 \mathrm{~min}$ at room temperature before measurements. Tryptophan fluorescence was measured with an excitation wavelength of $295 \mathrm{~nm}$, and the emission spectra were recorded between 300 and $400 \mathrm{~nm}$.

\section{Enzymatic characterization of Est8}

The enzymatic activity of purified Est8 was tested at different pHs (7.0, 8.0, and 9.0) on tributyrin-agar Petri dishes containing $0.23 \%(w / v)$ Tris, $1.2 \%(w / v)$ agar, and $1 \%(v / v)$ tributyrin. Est8 was prepared at a concentration of $50 \mu \mathrm{g} \mathrm{mL}^{-1}$ and $20 \mu \mathrm{L}$ was added to each dish. The material was incubated at $37^{\circ} \mathrm{C}$ for 1 day to verify the substrate hydrolysis and halo formation.

Kinetic parameters of Est 8 activity were obtained by measuring the formation of $p$-nitrophenol after para-nitrophenol ( $p$-NP) acyl ester hydrolysis. The reactions were measured against an enzyme-free sample that was used to subtract auto-hydrolysis, and the released $p$-nitrophenol was spectrophotometrically quantified at $405 \mathrm{~nm}$ using a 2104 Envision Multilabel Reader (PerkinElmer, Waltham, MA, USA). Absorbance readings were converted to $p$-NP concentration using molar absorption coefficient of $\varepsilon_{p^{-} \mathrm{NP}}=17,000 \mathrm{M}^{-1} \mathrm{~cm}^{-1}$. All assays were measured in triplicates in 96-well plates with a final volume of $100 \mu \mathrm{L}$, using JANUS Varispan automated liquid handler for plate preparation (PerkinElmer). Unless otherwise indicated, the reactions were developed at $25^{\circ} \mathrm{C}$ using $1 \mathrm{nM}$ of the enzyme, $1 \mathrm{mM}$ of substrates in $50 \mathrm{mM}$ Tris- $\mathrm{HCl} \mathrm{pH} 8.0$, and with $0.3 \%(v / v)$ Triton X-100. The enzyme activity was tested against different $p$-NP acyl esters [acetate $\left(\mathrm{C}_{2}\right)$, butyrate $\left(\mathrm{C}_{4}\right)$, and valerate $\left(\mathrm{C}_{5}\right)$; Sigma, San Louis, MO, USA]. The optimum temperature for Est8 activity was evaluated with $p$-NP acetate, and the measurements were performed in EnSpire Plate Reader (PerkinElmer), configured to make a temperature ramp from 25 to $55^{\circ} \mathrm{C}$. The $\mathrm{pH}$ optimum of Est8 was investigated using different buffering agents to establish a $\mathrm{pH}$ range from 5 to 10 (sodium citrate $\mathrm{pH} 5.0$ and 6.0; Tris- $\mathrm{HCl} \mathrm{pH} \mathrm{7.0,} \mathrm{8.0,} \mathrm{and} \mathrm{9.0;}$ and CHES $\mathrm{pH}$ 10.0). These reactions were performed with $p$-NP acetate as substrate. 
Est8 activity was tested in the presence of salts, metal ions, detergents, and solvents against $p$-NP acetate. The influence of metals $\left(\mathrm{Zn}^{2+}, \mathrm{Ni}^{2+}, \mathrm{Mn}^{2+}, \mathrm{Mg}^{2+}, \mathrm{K}^{+}, \mathrm{Co}^{2+}\right.$, and $\left.\mathrm{Ca}^{2+}\right)$ was measured in the presence of $0.5 \mathrm{mM}$ of each reagent and in the absence of them as a control. Est 8 's tolerance towards detergents and solvents was tested in the presence of Tween 20 or Triton X-100 [0.3125 to $5 \%(v / v)]$, dimethylformamide (DMF), or dimethyl sulfoxide (DMSO) [2.5 to $10 \%(v / v)]$. Control samples were prepared in the same conditions without detergents and solvents. The kinetic parameters were performed using $1 \mathrm{nM}$ of Est8 and $p$-NP acyl esters at concentration varying from 0.078 to $1 \mathrm{mM}$ at $25^{\circ} \mathrm{C}$. The catalytic rate constant $\left(K_{\text {cat }}\right)$ was calculated from the initial steady-state velocity according to the equation $K_{\mathrm{cat}}=V_{\max } /[E]$. The data from functional characterization of Est8 was analyzed using the $\mathrm{R}$ software. ANOVA and Tukey's test at $5 \%$ probability were used to make comparisons among the different conditions evaluated.

\section{Est8 crystallization}

Initial crystallization trials were performed in 96-well plates with 100 and $200 \mathrm{~nL}$ drop sizes using the following commercial kits: Crystal Screen and SaltRx (Hampton Research, Aliso Viejo, USA), JCSG suite and PACT suite (Qiagen, Hilden, Germany), and Precipitant synergy and Wizard I and II (Emerald BioSystems, Bainbridge Island, WA, USA). First crystals were obtained in $2 \%(v / v)$ polyethylene glycol (PEG) 8000 and $0.8 \mathrm{M}$ triammonium citrate $\mathrm{pH} 8.5$; this condition was refined by varying salt, protein concentrations, and $\mathrm{pH}$. Optimization plates were prepared manually through vapor-diffusion technique using $1: 1-$ and $1: 0.5-\mu \mathrm{L}$ ratios of protein and mother liquor and incubated at $18{ }^{\circ} \mathrm{C}$. Crystals were cryo-protected with $20 \%(v / v)$ glycerol in mother liquor and cryo-cooled in liquid $\mathrm{N}_{2}$.

\section{Data collection, processing, and structure refinement}

Diffraction data from cryo-cooled crystals were collected at the beamline I02 from Diamond Light Source, Oxfordshire, UK, using a Pilatus 6M detector. Datasets of Est8 were indexed and integrated using XDS (Kabsch 2010). The structure was solved by molecular replacement using Phaser program in CCP4 package (Winn et al. 2011) with Alicyclobacillus acidocaldarius carboxylesterase as a template model (PDB ID 1EVQ), which shares $43 \%$ of amino acid sequence identity with Est8. The structure was refined using REFMAC5 (Murshudov et al. 2011) and phenix. Refine programs and model were corrected manually using COOT (Emsley and Cowtan 2004). Analyses of the structures and figures were made with PyMOL (Delano 2010). All statistics from data collection and refinement are shown in Table S2 (Supplementary Information).

\section{Data bank accession codes}

The DNA sequence of est 8 gene was deposited at NCBI under the accession number KP699699, and the coordinates and structure factors of Est 8 were deposited in the PDB under accession code $4 \mathrm{YPV}$.

\section{Results}

\section{Est8 is a family IV member of esterases and lipases}

We screened our metagenomic library for esterases using colony assay on tributyrin containing agar plates. From the 30 clones that showed lipolytic activity, PL17.E10 clone was selected for sublibrary construction (Pereira et al. 2015). The gene annotation was carried out, and ORF8, which consists of $936 \mathrm{bp}$ (311 amino acids), was selected for further analysis among 25 ORFs. Its deduced amino acid sequence was submitted to BLASTp analysis at the NCBI, using the non-redundant protein sequence (nr) database, and showed $72 \%$ identity with an $\alpha / \beta$ hydrolase protein from Parvibaculum lavamentivorans (GenBank accession no. WP012110575.1) and 65\% identity with a carbohydrate esterase from Phaeomarinobacter ectocarpi (GenBank accession no. CDO59205.1). Moreover, against the metagenomic protein (env_nr) database, Est8 showed 52\% identity with hypothetical proteins from marine (GenBank accession no. EDJ20548.1) and freshwater metagenome (GenBank accession no. KGA15039.1), respectively.

To establish the phylogenetic relationships of Est8 within eight families of bacterial lipolytic enzymes as proposed by Arpigny and Jaeger (1999) and with esterases/lipases with known structure, a phylogenetic tree was built from selected sequences (Fig. 1a). The result evidenced that Est 8 belongs to the same branch as two previously described members from family IV, which are Cupriavidus necator (GenBank accession no. AAC41424.1) and Pseudomonas sp. (GenBank accession no. AAC38151.1). The structurally defined member of this family is $P$. calidifontis esterase (PDB ID 2YH2) (Palm et al. 2011), an enzyme that converts esters in acids and alcohols and showed high structural conservation with Est8 three-dimensional structure as evidenced by the lowest values of root-mean-square deviation (Fig. 1b). Structural superposition between Est8 and other representative members from each family also evidenced close structural relationship with families V and VI. As shown in the multiple sequence alignment (Fig. 1c), all the proteins shared conserved sequence motifs characteristic of family IV, also known as hormone-sensitive lipase (HSL) family, confirming the phylogenetic tree results. The conserved residues from the catalytic triad $\mathrm{Ser}^{159}-\mathrm{Asp}^{253}-\mathrm{His}^{283}$ were identified, which nucleophile Ser is positioned in the consensus pentapeptide motif 
GDSAG. The strictly conserved HGGG motif $\left(\mathrm{H}^{85}-\mathrm{G}^{86}-\mathrm{G}^{87}-\mathrm{G}^{88}\right)$ is located upstream of Est8 active site (Fig. 1c, in green).

\section{Kinetic characterization of Est8}

Recombinant Est8 protein was expressed with the expected molecular mass of $37 \mathrm{kDa}$ as calculated from its amino acid sequence and purified in two steps using a combination of Ni-NTA affinity and size exclusion chromatographies (Fig. S1-a, b, respectively, Supplementary Information). The pure Est 8 protein was recovered from second peak of the size exclusion chromatography with a final yield of $110 \mathrm{mg} \mathrm{mL}^{-1}$ per liter of induced culture. The protein remained stable even at high concentrations $\left(10-20 \mathrm{mg} \mathrm{mL}^{-1}\right)$ and during prolonged storage at $4{ }^{\circ} \mathrm{C}$.

Purified Est8 was submitted to circular dichroism analysis in neutral $(\mathrm{pH} 7.0)$ and basic $(\mathrm{pH} 9.0)$ conditions. The CD spectra obtained showed a typical mixed $\alpha / \beta$ spectrum with minima at 208 and $222 \mathrm{~nm}$, as expected for esterases/lipases (Nardini and Dijkstra 1999). Moreover, the spectra revealed that the $\mathrm{pH}$ tested did not alter the secondary structure (Fig. S1-c, Supplementary Information) or the denaturing temperature (Fig. S1-d, Supplementary Information) of Est8. Thermal denaturation of Est8 using CD showed a $T_{m}$ of $55^{\circ} \mathrm{C}$ $\left( \pm 1{ }^{\circ} \mathrm{C}\right)$.

Enzymatic analysis of Est8 showed that the enzyme was able to hydrolyze a very restricted range of substrates as $p$-NP acetate $\left(\mathrm{C}_{2}\right), p$-NP butyrate $\left(\mathrm{C}_{4}\right)$, and $p$-NP valerate $\left(\mathrm{C}_{5}\right)$ (Fig. 2a), which is in accordance with its denomination as an esterase (Jaeger et al. 1999). Est8 revealed the highest efficiency catalytic against $\mathrm{C}_{2}$ when compared with other esterases described in literature, as AFEST (Chahinian et al. 2005), EstFa_R (Ohara et al. 2014), and E40 (Li et al. 2015) (Table 1); furthermore, there is a greater catalytic efficiency for all substrates when compared to RmEstA esterase (Liu et al. 2013). Reactions against substrates with acyl esters with long-chain length $\left[p\right.$-NP decanoate $\left(\mathrm{C}_{10}\right)$ to $p$-NP palmitate $\left(\mathrm{C}_{16}\right)$ ] were performed but no activity was detected.

Based on the results of the analysis of substrate specificity, $p$-NP acetate was chosen for all the further analyses. Est8 is a mesophilic enzyme that presented optimum activity at $30{ }^{\circ} \mathrm{C}$, but showed relative activity above $43 \%$ in temperatures up to $55{ }^{\circ} \mathrm{C}$ (Fig. 2b), in accordance with its $T_{m}$ of $55{ }^{\circ} \mathrm{C}$ evidenced in the $\mathrm{CD}$ analysis (Fig. S1-d, Supplementary Information). Est8 showed the maximum activity at $\mathrm{pH} 9.0$ (Fig. 2c) and showed significant quenching of tryptophan fluorescence in presence of tributyrin as shown in Fig. 2 d, e. At $\mathrm{pH}$ 9.0 , besides the quenching, a displacement of the maximum peak of the spectrum to $320 \mathrm{~nm}$ is observed. These data are in accordance with the results presented for Est8 in Petri dishes plates that evidenced activity of the protein in basic $\mathrm{pH}$ (Fig. 2f).

In the presence of metal ions, the activity of Est8 showed no significant difference compared to the control, except for $\mathrm{Zn}^{2+}, \mathrm{Ni}^{2+}$, and $\mathrm{Co}^{2+}$ that reduced the activity to $3.9,73.9$, and 74.9, respectively (Fig. $2 \mathrm{~g}$ ). In the presence of increased concentrations of DMSO, the enzyme activity was similar to the one found in the control (up to $10 \%$ of this solvent) and still showed $65 \%$ of relative activity in the presence of $10 \% \mathrm{DMF}$ (Fig. 2h).

In presence of detergents (Triton X-100, NP-40, and Tween 20 ), the enzyme activity is gradually reduced down to $27 \%$ of basal activity at the highest $(5 \%)$ tested detergent concentration (Fig. 2i).

\section{Crystallization and structure determination}

Est8 crystal growth occurred until 6 days leading to bi-pyramidal crystals with dimensions ranging from 100 to $500 \mu \mathrm{m}$. Crystals were obtained in different crystallization conditions containing different polyethylene glycols and either 2-(N-morpholino)ethanesulfonic a c id ( M E S ) or 4-( 2 - h y d r o x y e t h y l) piperazine-1-ethanesulfonic acid (HEPES) buffers in $\mathrm{pH}$ 6.5-7.5. Refinement of all crystallization conditions lead to crystals grown in $1 \%(v / v)$ PEG $8000,1.4 \mathrm{M}$ triammonium citrate $\mathrm{pH} 9.0$ using $17.8 \mathrm{mg} \mathrm{mL}^{-1}$ of pure protein, which diffracted at maximum of $1.85-\AA$ resolution at Diamond Light Source. The data collected from Est 8 crystals showed the symmetry and systematic absences of the primitive hexagonal space group $\mathrm{P} 3{ }_{1} 2_{1}$. The Matthews coefficient was $3.35 \AA^{3} / \mathrm{Da}$, and the solvent content $63.4 \%$ correspond to estimated one Est8 molecule in the asymmetric unit. The structure was solved using molecular replacement using A. acidocaldarius carboxylesterase (43\% sequence identity) as a search model. The structure was refined and manually corrected resulting in a model with good stereochemistry and refinement statistics. Table S2 (Supplementary Information) summarizes the data collection and refinement statistics.

The refined structure of Est8 displays the conserved structure of esterases from the HSL family that shows an ellipsoidal shape defined by an $\alpha / \beta$ hydrolase fold, in which two domains can be identified, which are a globular catalytic domain and a helical cap domain that covers the entrance to the active site (Fig. 3a, green/ orange and pale yellow, respectively). The catalytic domain has a mixed $\beta$-sheet composed of eight $\beta$-strands (only strand $\beta 2$ is antiparallel) surrounded by the following ten helices: Pro $^{5}-\mathrm{Ala}^{16}, \mathrm{Ile}^{22}-\mathrm{Asp}^{24}, \mathrm{Val}^{27}-\mathrm{Leu}^{41}$, $\mathrm{Thr}^{96}-\mathrm{Ala}^{108}, \quad \mathrm{~A} 1 \mathrm{a}^{127}-\mathrm{Ile}^{146}, \mathrm{Ala}^{160}-\mathrm{Ala}^{175}$, $\mathrm{Ala}^{197}-\mathrm{Asn}^{202}, \operatorname{Arg}^{210}-\mathrm{Tyr}^{220}, \mathrm{Leu}^{255}-\mathrm{Ala}^{269}$, and 
a
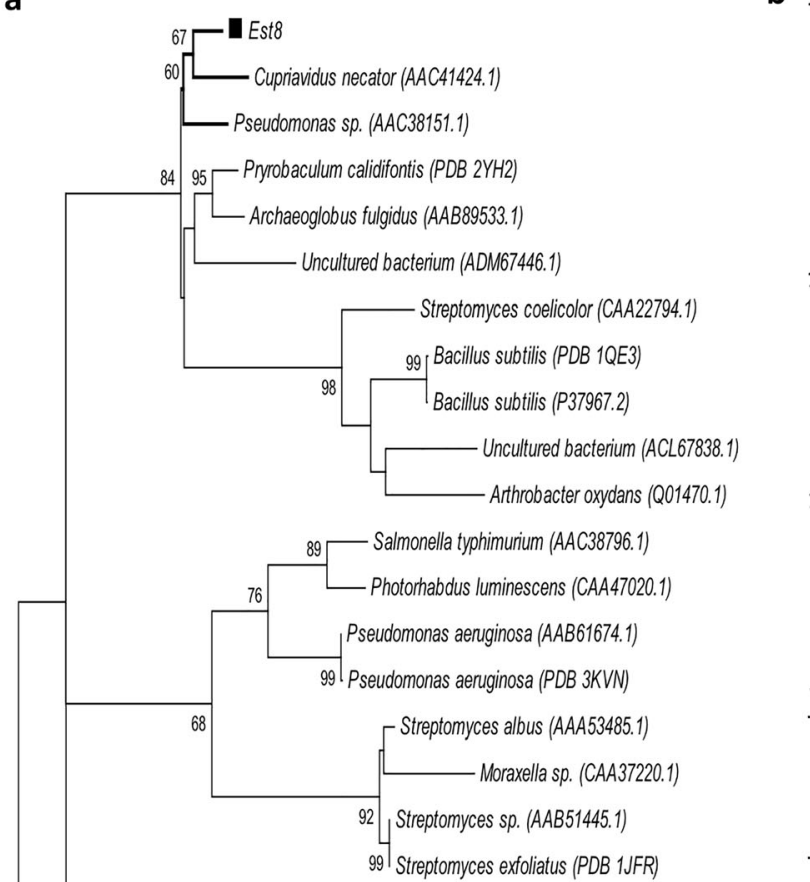

96-Psychrobacter immobilis (CAA47949.1)

Moraxella sp. (CAA37863.1)

58

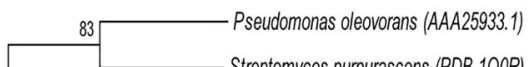

Streptomyces purpurascens (PDB 1Q0R)

Burkholderia glumae (CAA49812.1)

97

[ Burkholderia cepacia (AAA50466.1)

67 Pseudomonas luteola (AAC05510.1)

Pseudomonas cepacia (PDB 10IL)

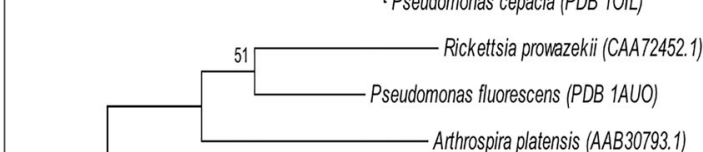

- Arthrospira platensis (AAB30793.1)

Chlamydia trachomatis (AAC67727.1)

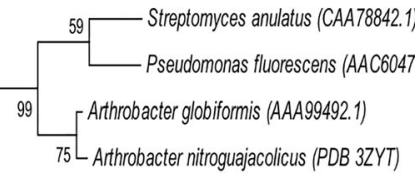

VIII $\mathrm{rmsd}=15.0$

III $\mathrm{rmsd}=6.2$

V $\mathrm{rmsd}=\mathbf{2 . 4}$

$\mathrm{rmsd}=7.5$

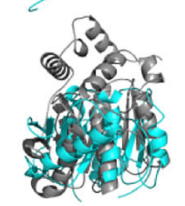

VI $\quad$ rmsd $=2.3$

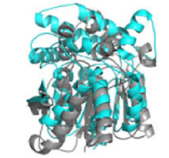

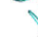
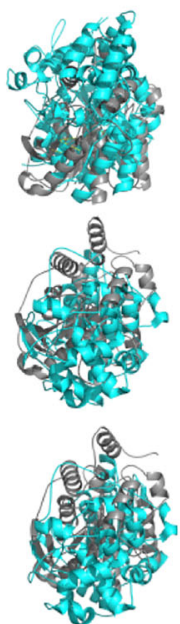

c

Est8 81 LVYFHGGGWV $90 \quad 155$ VAGDSAGGNLA 165 AAC41424.1 126 LVYFHGGGFT 135 200 VGGDSAGGTLA 210 PDB: 2YH2 79 VVYYHGGGFV 88 153 VAGDSAGGNLA 163 $::: \star \star \star \star:$

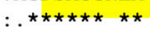

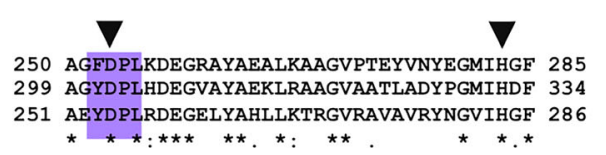

$\alpha / \beta$-fold (root-mean-square deviation (rmsd) of $0.6 \AA$ ) (Fig. 3b) and identical positioning of the catalytic triad residues (Fig. 3c, cyan stick).

The catalytic nucleophile $\mathrm{Ser}^{159}$ is positioned between $\beta 5$ and $\alpha 6$, in the consensus pentapeptide motif GDSAG (Fig. 3c, yellow cartoon), while the other two 
Fig. 1 Phylogenetic analysis of Est8 and sequence comparison with orthologues. a Phylogenetic tree of Est8. Representative members of eight bacterial lipolytic families and representative structurally characterized members for each class are shown. Accession numbers at NCBI database (for sequences) or PDB (for structures) are shown in parenthesis after the enzyme name. Multiple sequence alignment was performed with ClustalW and used as input for building the phylogenetic tree in MEGA 6.0 program based on the maximum likelihood method with a bootstrap of 1000 replicates. The estimated value of the shape parameter for the discrete gamma distribution was 11.9665. Substitution pattern and rates were estimated under the WAG model $(+\mathrm{G}+\mathrm{F})$ with two categories. Scale bar number of amino acids substitutions per site. b Structural differences between Est8 and members of each family shown by the rmsd. values obtained after the structural superposition. Est8 and one PDB member identified in the tree are, respectively, shown in gray and cyan cartoon. Members of family IV and $\mathrm{V}$ show the highest structural similarity with Est8. c Amino acid sequence alignment of Est8, Cupriavidus necator lipase (accession number AAC41424.1) and Pyrobaculum calidifontis esterase (PDB ID $2 \mathrm{YH} 2$ ), proteins classified in branch of family IV and their functional motifs. Amino acids that belong to the catalytic triad are indicated by arrow (black inverted triangle), and characteristic motifs from family IV are colored. All the sequences used in this figure are described in Table S1 (Supplementary Information)

residues $\left(\mathrm{Asp}^{253}\right.$ and $\mathrm{His}^{283}$ ) are found between $\beta 7$ and $\alpha 9$ and between $\beta 8$ and $\alpha 10$, respectively (Fig. $3 \mathrm{c}$, cyan stick). The three amino acids in the catalytic triad are in close proximity with the residues that are involved in the formation of oxyanion hole during catalysis such as the strictly conserved HGGG motif (Fig. 3c, green sticks) (Wei et al. 1999). Other motifs that are involved in catalytic mechanism in members of family IV esterases, such as ${ }^{157}$ GXSXGGNL $^{164}$ (yellow cartoon) and ${ }^{253} \mathrm{DPXXD}^{257}$ (blue cartoon), are evident in the structure.

Interestingly, although Est8 and P. calidifontis esterase belong to the same family and conserve exactly the same three-dimensional structure, when the ligand-binding pockets are compared, we observed quite different channels (Fig. 4a, b, shown in colored surface). In fact, a BLASTp using Est8 sequence versus the PDB returned five other esterases/lipases that share the same fold with slight differences but show different catalytic activities (Table 1). The three enzymes that only accept two carbon substrates [Est8, Pseudomonas putida ECU1011 esterase (4OB8), and heroin esterase (1LZL)] do not have extended channel as observed in the other enzymes that are capable of cleaving larger substrates (Fig. 4). These differences are likely to be important for the selectivity towards particular substrates. In the comparison with many of the other related esterases, Est8 has a relative small active site cavity, lacking the extended substrate channel, in line with the higher activity it demonstrates against $p$-NP acetate $\left(\mathrm{C}_{2}\right)$. This is similar to other esterases that prefer substrates with short acyl chain, as shown in Fig. 4c, d. In contrast, enzymes that have larger channels show significant activity also for substrates with longer acyl chains, such as $p$-NP butyrate $\left(\mathrm{C}_{4}\right), p$-NP hexanoate $\left(\mathrm{C}_{6}\right)$, and $p$-NP octanoate $\left(\mathrm{C}_{8}\right)$ (Fig. $4 \mathrm{~b}-\mathrm{f}$ ).

\section{Comparison of Est8 with Est3 and Est16}

The amino acid sequence identity shared by the enzymes with Est 8 is 80 and 13\%, respectively, for Est3 and Est16 (Fig. 5a). Structurally, the proteins show significant differences in the number and organization of the helices from the cap domains as evidenced in Fig. 5a (gray cartoon). Interestingly, even belonging to the same family and sharing $80 \%$ of amino acid sequence identity, we can observe that the channel for entrance and fitting of the substrate in Est3 and Est8 proteins are quite different. Est 8 has a small cavity, Est3 a long channel, and Est16 shows a long cavity that is also more exposed (Fig. 5b). These structural features lead to the differences observed in the kinetic parameters that revealed a higher efficiency of Est8 against short chains, especially against $\mathrm{C}_{2}$, while the two other enzymes cannot hydrolyze these substrates. On the other hand, the reduced cavity shown in Est8 must be one of the reasons for its absence of activity against $\mathrm{C}_{8}$ (Fig. 5c).

\section{The opening of the channel for substrate in Est8 is not enough to increase the catalytic parameters of the enzyme}

Comparing Est8 active site cavity with structures of enzymes with open substrate-binding channel, we observed that the residues $\mathrm{Met}^{213}$ and $\mathrm{Phe}^{217}$ appear to block the channel, restricting the enzyme to accept only short-chain substrates. To verify if the opening of the channel would induce differences in the activity of the enzyme, we generated the mutations $\mathrm{Met}^{213} \mathrm{Gly}$ and Phe ${ }^{217}$ Val (Est8MF). As we were unable to determine the structure of the mutant protein, to predict the effect of the mutations on the channel, we built a model of Est8MF based on the Est8 wild-type structure. As expected, the mutations are predicted to result in the opening of the channel (Fig. 6a, b). After induction of E. coli BL21 (DE3) cells carrying the vector pHAT2-est8mf and purification of the mutant protein, as described in the "Material and methods" section, the kinetics of Est8MF was performed. The mutations induced an increasing of fourfold and twofold in the activity of enzyme against the substrates $p$-NP butyrate $\left(\mathrm{C}_{4}\right)$ and $p$-NP valerate $\left(\mathrm{C}_{5}\right)$ (Fig. $6 \mathrm{c}$ ), respectively, but drastically reduced the activity against $p$-NP acetate $\left(\mathrm{C}_{2}\right)$ as well (Table 1). 
a

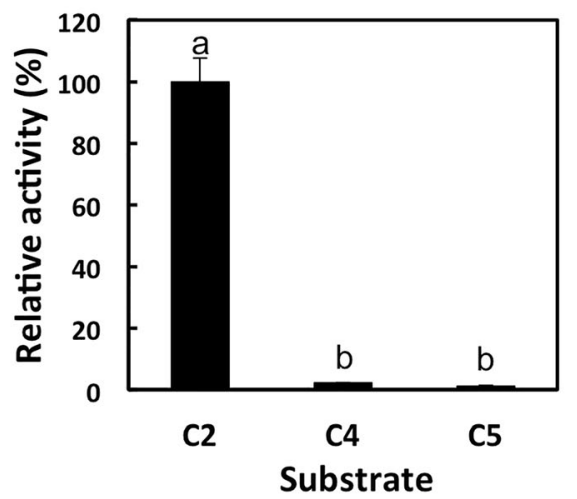

d

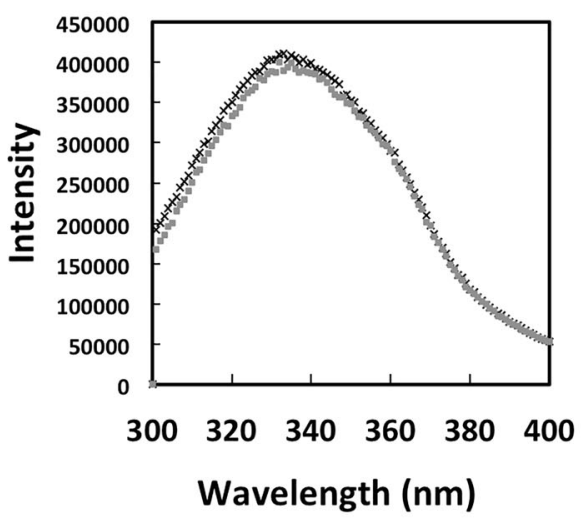

g

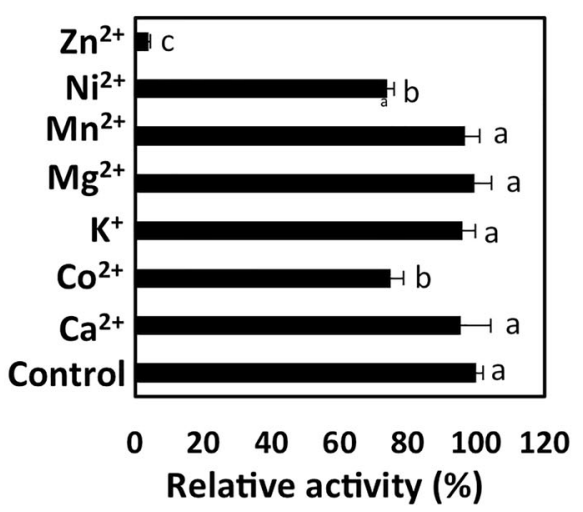

b

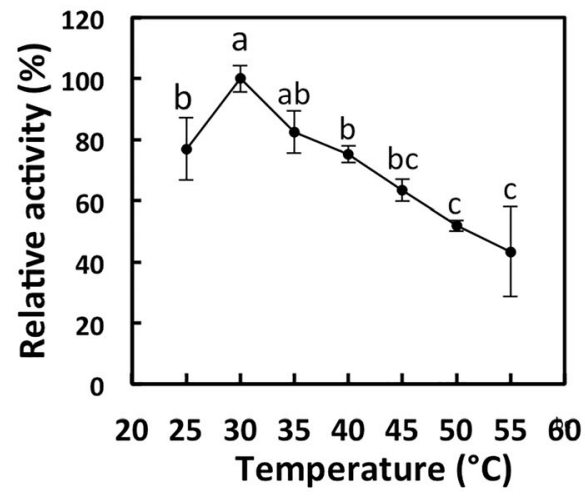

e

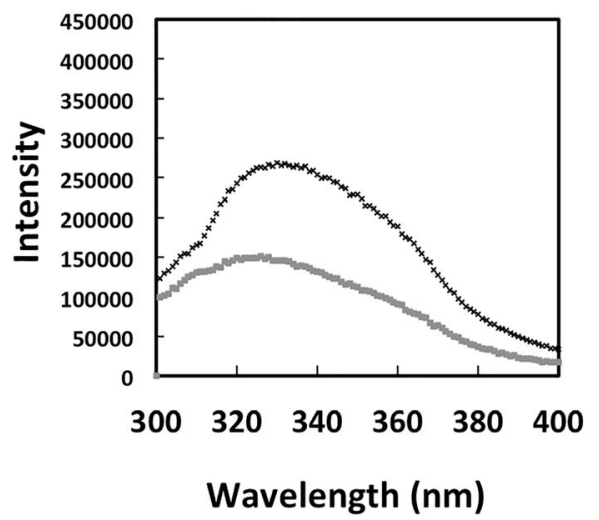

h

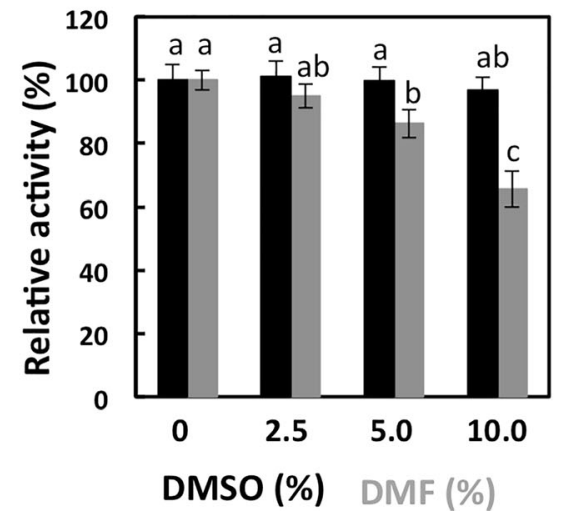

C

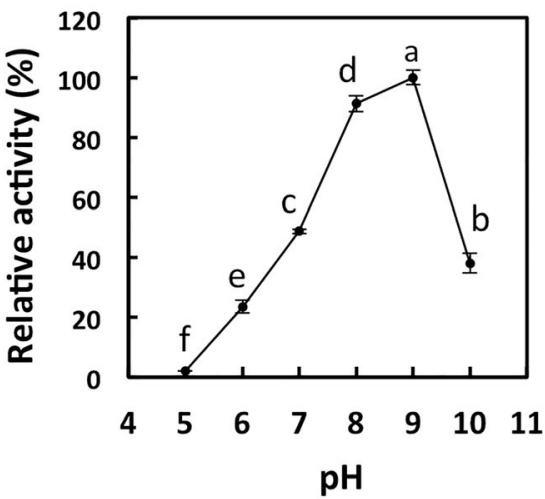

f

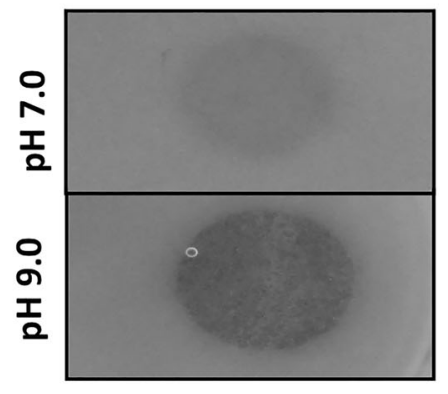

Fig. 2 Enzymatic characterization of Est8. a Substrate specificity of Est8 against $p$-nitrophenyl acetate $\left(\mathrm{C}_{2}\right), p$-nitrophenyl butyrate $\left(\mathrm{C}_{4}\right)$, and $p$ nitrophenyl valerate $\left(\mathrm{C}_{5}\right)$. b The effect of temperature in the enzymatic activity using $p$-nitrophenyl acetate as a substrate with measures taken at every $5{ }^{\circ} \mathrm{C}$ from 25 to $55^{\circ} \mathrm{C}$. c The effect of $\mathrm{pH}$ on the enzymatic activity, measured on $\mathrm{pH}$ ranging from 5.0 to 10.0. d Tryptophan fluorescence spectrum of Est8 at pH 7.0 (black line) and 9.0 (gray line) in the absence of tributyrin. e Tryptophan fluorescence spectrum of Est8 at pH 7.0 (black line) and 9.0 (gray line) in the presence of tributyrin. f Agar containing $1 \%(v / v)$ tributyrin onto which $1 \mu \mathrm{M}$ of Est8 has been spotted. The experiment was performed at room temperature, and a clear halo indicated esterase activity. $\mathbf{g}$ Influence of ions on Est8 activity. Control samples were prepared with no additives. h Influence of solvents. Black and dark gray bars correspond to DMSO and DMF, respectively. $\mathbf{i}$ Influence of detergents in the enzyme activity. Triton X-100 (black bar), NP-40 (dark gray bar), and Tween 20 (gray bar). All data are mean values of three independent measures, and the standard deviations are indicated by error bars. In the graphics $(\mathbf{a}-\mathbf{c}$ and $\mathbf{g - i})$, the small letters indicate the significant difference between each condition performed in the experiment, according to ANOVA and Tukey's test at 5\% probability 
Table 1 Kinetic parameters of Est8 and Est8MF and comparison with other esterases/lipases described in the literature

\begin{tabular}{|c|c|c|c|c|c|c|c|c|}
\hline Protein & Description & Source & Substrate & $K_{\text {cat }}\left(\mathrm{s}^{-1}\right)$ & $K_{m}(\mathrm{mM})$ & $\begin{array}{l}K_{\mathrm{cat}} / K_{m} \\
\left(\mathrm{~s}^{-1} \mathrm{mM}^{-1}\right)\end{array}$ & $\begin{array}{l}\text { PDB } \\
\text { code }\end{array}$ & Reference \\
\hline \multirow[t]{3}{*}{ Est8 } & \multirow[t]{3}{*}{ Esterase } & \multirow[t]{3}{*}{ Metagenomic } & $p$-NP acetate $\left(\mathrm{C}_{2}\right)$ & $1,484 \pm 52.6$ & $0.224 \pm 0.02$ & $6,619.1$ & \multirow[t]{3}{*}{ 4YPV } & \multirow[t]{3}{*}{ This work } \\
\hline & & & $\begin{array}{l}p \text {-NP butyrate } \\
\left(\mathrm{C}_{4}\right)\end{array}$ & $23.72 \pm 1.1$ & $0.056 \pm 0.01$ & 425.03 & & \\
\hline & & & $\begin{array}{l}p \text {-NP valerate } \\
\left(\mathrm{C}_{5}\right)\end{array}$ & $13.67 \pm 0.52$ & $0.245 \pm 0.03$ & 55.76 & & \\
\hline \multirow[t]{3}{*}{ Est8MF } & \multirow[t]{3}{*}{ Esterase } & \multirow[t]{3}{*}{ Metagenomic } & $p$-NP acetate $\left(\mathrm{C}_{2}\right)$ & $11.38 \pm 1.68$ & $0.125 \pm 0.06$ & 91.14 & \multirow[t]{3}{*}{-} & \multirow[t]{3}{*}{ This work } \\
\hline & & & $\begin{array}{l}p \text {-NP butyrate } \\
\left(\mathrm{C}_{4}\right)\end{array}$ & $65.65 \pm 2.27$ & $0.745 \pm 0.06$ & 88.07 & & \\
\hline & & & $\begin{array}{l}p \text {-NP valerate } \\
\left(\mathrm{C}_{5}\right)\end{array}$ & $25.27 \pm 4.32$ & $0.78 \pm 0.25$ & 32.39 & & \\
\hline \multirow[t]{5}{*}{ PestE } & \multirow[t]{5}{*}{ Esterase } & \multirow[t]{5}{*}{$\begin{array}{l}\text { Pyrobaculum } \\
\text { calidifontis }\end{array}$} & $\begin{array}{l}p \text {-NP propionate } \\
\left(\mathrm{C}_{3}\right)\end{array}$ & $1,480 \pm 110$ & $0.348 \pm 0.08$ & $4,252.9$ & \multirow[t]{5}{*}{$2 \mathrm{YH} 2$} & \multirow[t]{5}{*}{$\begin{array}{l}\text { Hotta et al. } \\
\text { (2002) }\end{array}$} \\
\hline & & & $\begin{array}{l}p \text {-NP butyrate } \\
\left(\mathrm{C}_{4}\right)\end{array}$ & $1,690 \pm 20$ & $0.164 \pm 0.007$ & 10,305 & & \\
\hline & & & $\begin{array}{l}p \text {-NP valerate } \\
\left(\mathrm{C}_{5}\right)\end{array}$ & $2,070 \pm 80$ & $0.071 \pm 0.01$ & 29,155 & & \\
\hline & & & $\begin{array}{l}p \text {-NP caproate } \\
\left(\mathrm{C}_{6}\right)\end{array}$ & $2,620 \pm 90$ & $0.044 \pm 0.006$ & 59,009 & & \\
\hline & & & $\begin{array}{l}p \text {-NP caprylate } \\
\left(\mathrm{C}_{8}\right)\end{array}$ & $1,600 \pm 270$ & $0.051 \pm 0.026$ & 31,373 & & \\
\hline HerE & Acetyl esterase & Rhodococcus sp. & 6-acetylmorphine & $12.6 \pm 0.6$ & $0.5 \pm 0.06$ & 25.2 & 1LZL & Zhu et al. (2003) \\
\hline & & & phenyl acetate & $3.0 \pm 0.05$ & $7 \times 10^{-5} \pm 8 \times 10^{-6}$ & 42,857 & & \\
\hline \multirow[t]{3}{*}{ EstE1 } & \multirow[t]{3}{*}{ Esterase } & \multirow[t]{3}{*}{ Metagenomic } & Butyrate $\left(\mathrm{C}_{4}\right)$ & 2,950 & 2.3 & 1,280 & \multirow[t]{3}{*}{$2 \mathrm{C} 7 \mathrm{~B}$} & \multirow{3}{*}{$\begin{array}{l}\text { Rhee et al. } \\
\quad(2005)\end{array}$} \\
\hline & & & Valerate $\left(\mathrm{C}_{5}\right)$ & 1,300 & 0.6 & 2,170 & & \\
\hline & & & Caproate $\left(\mathrm{C}_{6}\right)$ & 1,600 & 0.7 & 2,290 & & \\
\hline \multirow[t]{3}{*}{ AFEST } & \multirow[t]{3}{*}{ Carboxyesterase } & \multirow{3}{*}{$\begin{array}{l}\text { Archaeoglobus } \\
\quad \text { fulgidus }\end{array}$} & Triacetin $\left(\mathrm{C}_{2}\right)$ & 40 & 10 & 4 & \multirow[t]{3}{*}{$1 \mathrm{JJI}$} & \multirow{3}{*}{$\begin{array}{l}\text { Chahinian et al. } \\
\text { (2005) }\end{array}$} \\
\hline & & & Tripropionin $\left(\mathrm{C}_{3}\right)$ & 110 & 0.3 & 366.67 & & \\
\hline & & & Tributyrin $\left(\mathrm{C}_{4}\right)$ & 95 & 0.05 & 1,900 & & \\
\hline \multirow[t]{4}{*}{ EstFa_R } & \multirow[t]{4}{*}{ Carboxylesterase } & Ferroplasma & $p$-NP acetate $\left(\mathrm{C}_{2}\right)$ & $13 \pm 1$ & $0.73 \pm 0.12$ & 17.8 & $3 \mathrm{WJ} 2$ & Ohara et al. \\
\hline & & acidiphilum & $\begin{array}{l}p \text {-NP propionate } \\
\left(\mathrm{C}_{3}\right)\end{array}$ & $28 \pm 2$ & $0.37 \pm 0.07$ & 74.4 & & (2014) \\
\hline & & & $\begin{array}{l}p \text {-NP butyrate } \\
\left(\mathrm{C}_{4}\right)\end{array}$ & $56 \pm 3$ & $0.32 \pm 0.05$ & 173 & & \\
\hline & & & $\begin{array}{l}p \text {-NP caproate } \\
\left(\mathrm{C}_{6}\right)\end{array}$ & $11 \pm 1$ & $0.13 \pm 0.04$ & 79.5 & & \\
\hline RmEstA & Esterase & Rhizoтисог & $p$-NP acetate $\left(\mathrm{C}_{2}\right)$ & 0.37 & 1 & 0.37 & 4WY5 & Liu et al. (2012) \\
\hline & & miehei & $\begin{array}{l}p \text {-NP butyrate } \\
\left(\mathrm{C}_{4}\right)\end{array}$ & 1.17 & 0.17 & 6.90 & & \\
\hline & & & $\begin{array}{l}p \text {-NP hexanoate } \\
\left(\mathrm{C}_{6}\right)\end{array}$ & 1.08 & 0.12 & 8.97 & & \\
\hline & & & $\begin{array}{l}p \text {-NP caprylate } \\
\left(\mathrm{C}_{8}\right)\end{array}$ & 0.42 & 0.82 & 0.51 & & \\
\hline & & & $\begin{array}{l}p \text {-NP decanoate } \\
\left(\mathrm{C}_{10}\right)\end{array}$ & 0.04 & 0.28 & 0.13 & & \\
\hline & & & $\begin{array}{l}p \text {-NP laurate } \\
\left(\mathrm{C}_{12}\right)\end{array}$ & 0.02 & 3 & 0.06 & & \\
\hline RmEstB & Esterase & Rhizoтисог & $p$-NP acetate $\left(\mathrm{C}_{2}\right)$ & 0.195 & 1.6 & 0.122 & $4 \mathrm{WY} 8$ & Yang et al. \\
\hline & & miehei & $p$-NP butyrate & 0.086 & 1.1 & 0.078 & & (2015) \\
\hline & & & $\begin{array}{l}p \text {-NP hexanoate } \\
\left(\mathrm{C}_{6}\right)\end{array}$ & 0.031 & 5.6 & 0.005 & & \\
\hline & & & $\begin{array}{l}p \text {-NP caprylate } \\
\left(\mathrm{C}_{8}\right)\end{array}$ & 0.0190 .004 & 4.76 .5 & 0.0040 .0007 & & \\
\hline $\mathrm{E} 40$ & Esterase & Metagenomic & $\begin{array}{l}p \text {-NP butyrate } \\
\left(\mathrm{C}_{4}\right)\end{array}$ & 247 & 0.24 & 1,000 & $4 \mathrm{XVC}$ & Li et al. (2015) \\
\hline
\end{tabular}

$C_{2} p$-NP-acetate, $C_{3} p$-NP-propionate, $C_{4} p$-NP-butyrate, $C_{5} p$-NP-valerate, $C_{6} p$-NP-caproate, $C_{8} p$-NP-caprylate, $C_{10} p$-NP-decanoate, $C_{12} p$-NPlaurate, 6-ACPA acetyl morphine phenyl acetate 


\section{a}

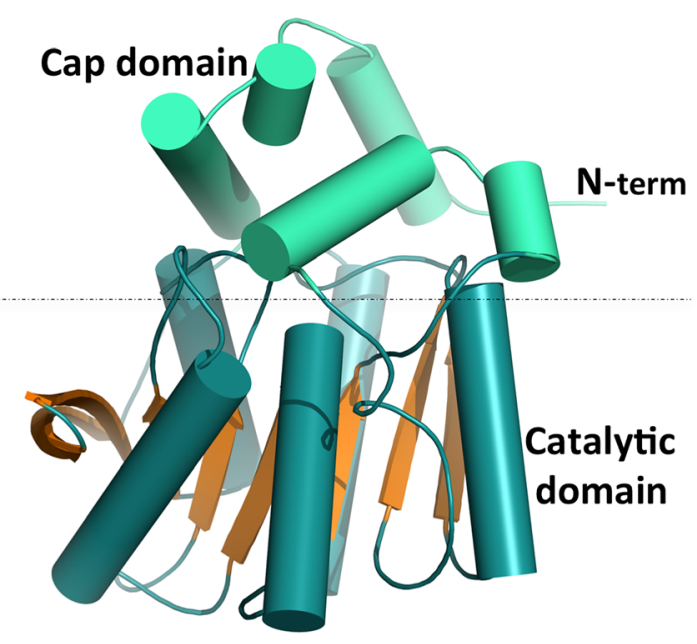

b

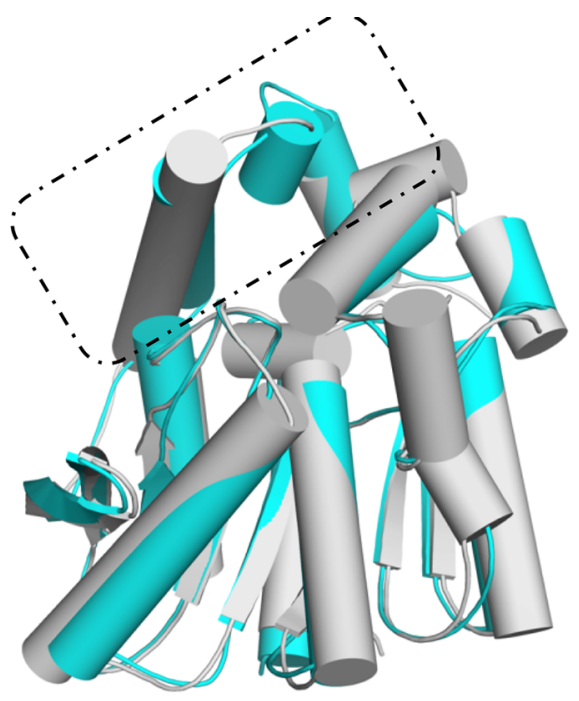

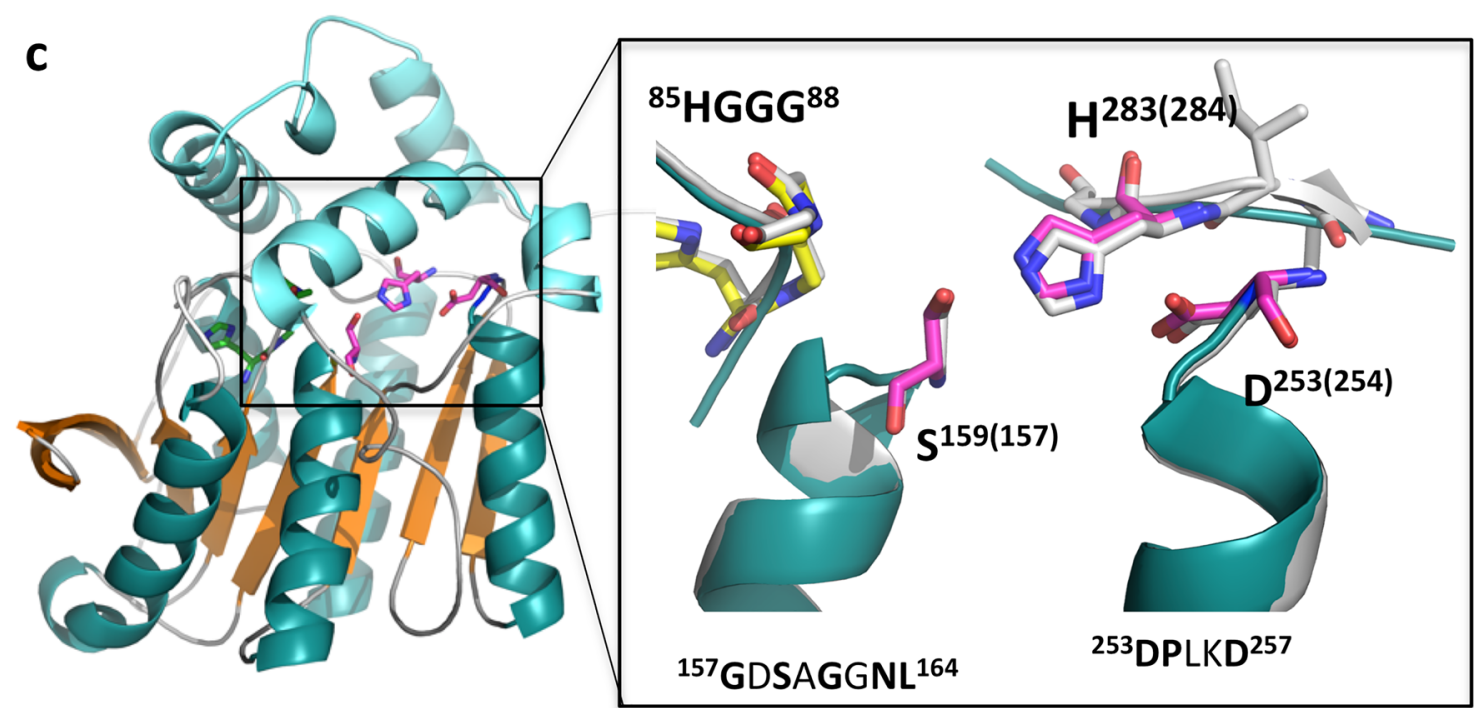

Fig. 3 Three-dimensional structure of Est8. a Cartoon representation of Est 8 three-dimensional structure showing the cap domain (above the line) and catalytic domain (below the line). The catalytic domain consists of a $\beta$-sheet (orange) with eight $\beta$-strands surrounded by helices (cyan) forming a structure that sustains the active site. b Structural superposition of Est8 (cyan) and Pyrobaculum calidifontis esterase (PDB ID 2YH2; gray). The most significant difference in the cap domain is highlighted

with a dotted rectangle. This structural feature is related to the accessibility to the active site and the volume of the enzyme pocket. The rmsd between both proteins is shown. c Overall positioning of the catalytic triad inside Est8 and detail of the superimposition of enzyme with the $P$. calidifontis esterase (residues shown in cyan stick). In Est8, the residues from the HGGG motif are shown in yellow, and those from catalytic triad are shown in pink stick

$\mathrm{CD}$ analyses revealed that Est8MF folding was not affected when compared to the wild type with slight differences in the helix content, as observed in the region 195 to $210 \mathrm{~nm}$ from the spectra (Fig. 6d). Similarly, the presence of substrates $p$-NP acetate $\left(\mathrm{C}_{2}\right)$ or $p$-NP butyrate $\left(\mathrm{C}_{4}\right)$ did not induce any difference in the folding of the mutant protein (Fig. 6e) but there is an increase of the $T_{m}$ up to $4^{\circ} \mathrm{C}$, suggesting that the substrates help the protein stability (Fig. 6f).

\section{Discussion}

In this work, we showed the functional and structural characterization of Est8, a novel esterase isolated from oil-contaminated soil through metagenomic approach, in comparison with other orthologues previously characterized. The enzyme is a new member of family IV of bacterial lipolytic enzymes that showed stability in the 
a

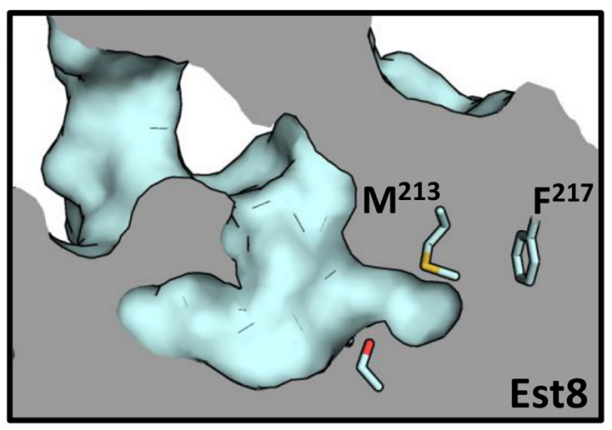

(C2)

C

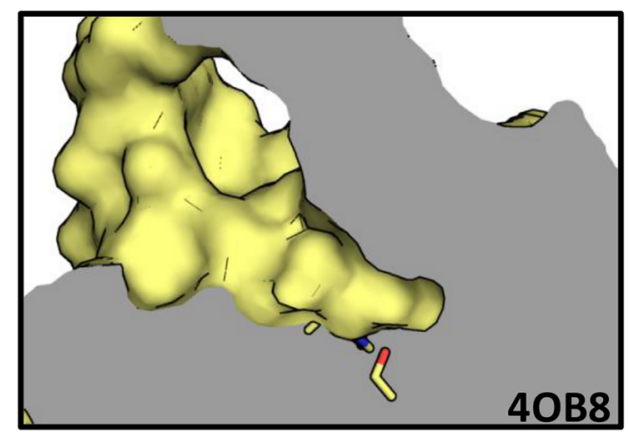

( $\alpha$-acetoxyphenylacetate )

e

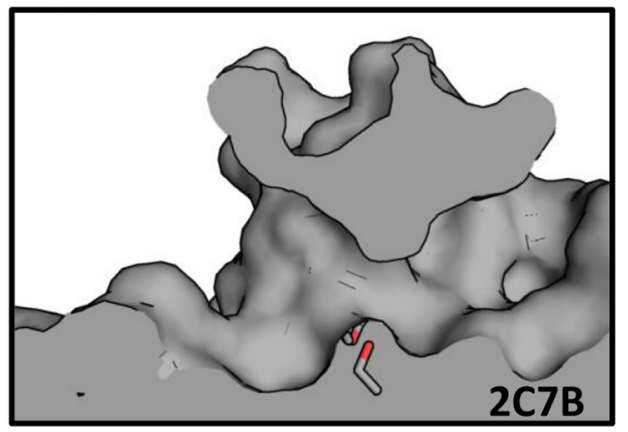

$(\mathrm{C} 4, \mathrm{C5}, \mathrm{C6})$

Fig. 4 Comparison of the substrate channel in different esterases/lipases that share similar fold with Est8. The figures show a cut-through of the structures with the gray surfaces show solid parts of the protein. On the other hand, the colored molecular surface lines show the active site cavities of the proteins. The enzymes are a Est8, b Pyrobaculum calidifontis

presence of up to $10 \%(v / v)$ DMSO, optimum catalytic activity at $30{ }^{\circ} \mathrm{C}$, highest efficiency catalytic against $p$-NP acetate, and melting temperature around $50{ }^{\circ} \mathrm{C}$. Despite the structural conservation in members of family IV, we showed that the cap domain region in these proteins could be variable defining the cavity for b

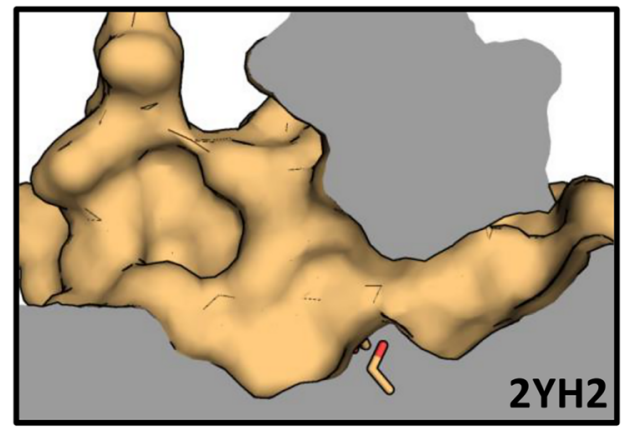

(C3, C4, C8)

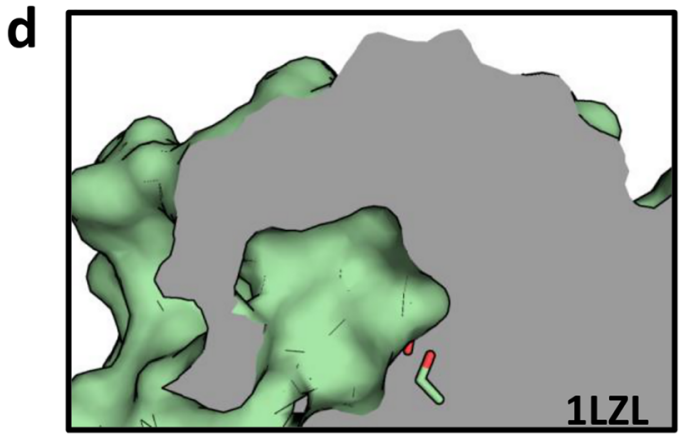

(6-acetyl morphine)

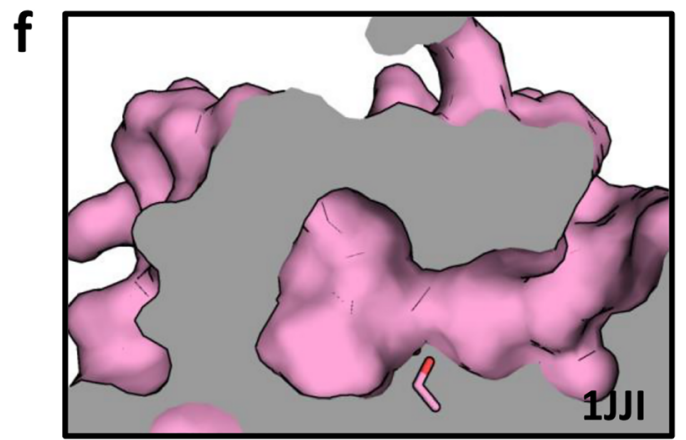

$(\mathrm{C} 2, \mathrm{C} 3, \mathrm{C} 4)$

esterase (PDB ID 2YH2), c Pseudomonas putida ECU1011 esterase (PDB ID 4OB8), d heroin esterase (PDB ID 1LZL), e ESTE1 carboxylesterase (PDB ID 2C7B), and f Archaeoglobus fulgidus carboxylesterase (PDB ID 1JJI). The best substrates for each enzyme are shown in parenthesis under the figures

substrate, the substrate range, and kinetic parameters. This observation is evidenced mainly when we compared structures belonging to the same family as Est8 and Est3 (Figs. 4 and 5). Even sharing $80 \%$ of identity, the differences in cap domain and cavity for substrate affect the $\mathrm{pH}$ range for activity (lower in Est3, pH 6 to 
Fig. 5 Comparison among the enzymes Est8, Est3, and Est16. a Crystallographic structure of Est8 and the molecular models of Est3 and Est16 are shown in cartoon. The small domain or cap domain in HSL enzymes is shown in gray. Beta-sheet from the catalytic domains are shown in orange. The amino acid sequence identity is shown based on the Est8 protein. The models of Est 16 and Est3 were built according to Pereira and collaborators (2015) and Maester and collaborators (2016), respectively. b Internal cavities or channels for substrate interaction showed in surface mode for the crystallographic structure of Est8 and molecular models of Est 3 and Est16. The internal pockets are evidenced in black. All the structures are positioned in the same way with lateral view, cap domain in the up side and $\mathrm{N}$ terminal end on the right. c Comparison of the catalytic parameters of the enzymes against different substrates
A

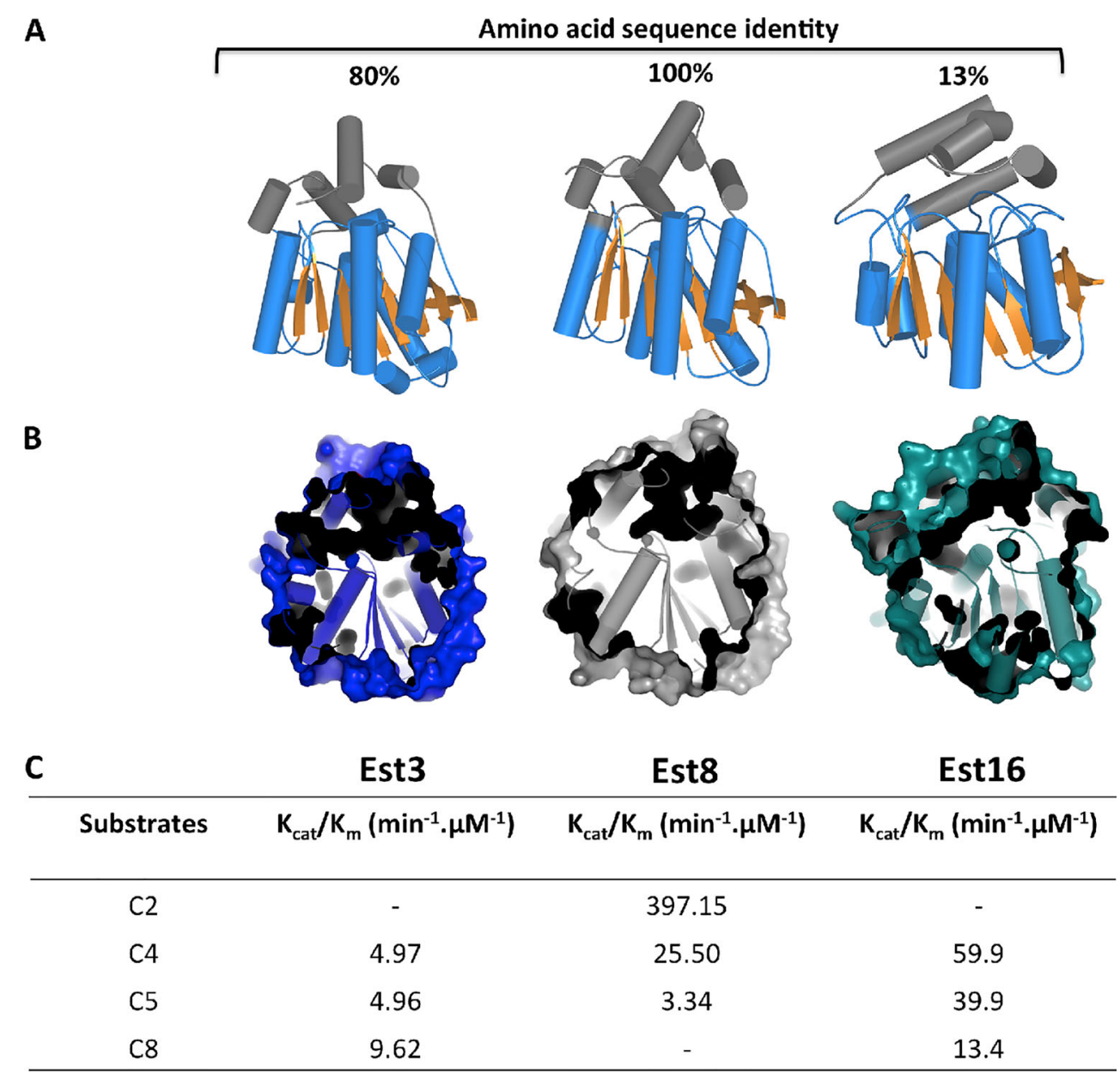

A
8), substrates, and response to organic solvents and detergents (Maester et al. 2016). The small cavity evidenced by Est 8 structure and the location of the nucleophile $\operatorname{Ser}^{159}$ in this cavity explain its selected high activity against $\mathrm{C}_{2}$ shown in the kinetic analyses. In comparison with the Rhizomucor miehei esterase EstB (Rm EstB) (Yang et al. 2015), an enzyme that also showed high activity against $\mathrm{C}_{2}$, Est8 is still more effective (Table 1). Similarly, both enzymes have small cavities constricted by the presence of aromatic residues that restrict carbon chain of long lengths, such as $\mathrm{Met}^{213}$ and $\mathrm{Phe}^{217}$ in Est8 and Trp ${ }^{92}$ and $\mathrm{Phe}^{222}$ in Rm EstB (Yang et al. 2015). In Est8, when mutations Met $^{213}$ Gly and Phe ${ }^{217}$ Val were performed, changes in the previous steric hindrance led to an increasing of the relative activity against $\mathrm{C}_{4}$ and $\mathrm{C}_{5}$ as expected. However, the changes induced a dramatic effect in the activity against $\mathrm{C}_{2}$, suggesting that the constricted acyl-binding site is important for the activity against this substrate.

Another important characteristic that might be interesting for industrial applications is the broad temperature range. Est8 was isolated from soils where the temperature usually gets more than $30^{\circ} \mathrm{C}$ and showed relative activity of $40 \%$ for all temperatures up to $50{ }^{\circ} \mathrm{C}$. Its mild thermal stability might be attributed to the fact that Est8 is a monomeric protein and does not present interactions between ion pairs in the catalytic domain, as pointed to be one of the essential factors for the stability in the monomeric enzyme Est2 from A. acidocaldarius (Manco et al. 2001). In hyperthermophilic enzymes, EstE1 from thermal environment (Byun et al. 2007), PestE from P. calidifonti (Mandrich et al. 2005), and Sto-Est from Sulfolobus tokodaii (Angkawidjaja et al. 2012) oligomerization is pointed as an important factor for stability due the increasing in the number of hydrogen bonds and hydrophobic interactions between the monomers. CD analyses revealed that there are no differences in the secondary structure content in different $\mathrm{pH}$ but there is a slight increase in the $T_{m}$ at $\mathrm{pH} \mathrm{9.0,} \mathrm{the} \mathrm{same} \mathrm{pH}$ where the protein suffered a pronounced quenching of tryptophans after addition of trybutyrin. This result suggests that in presence of the substrate, the protein could assume a more stable structure. 
a

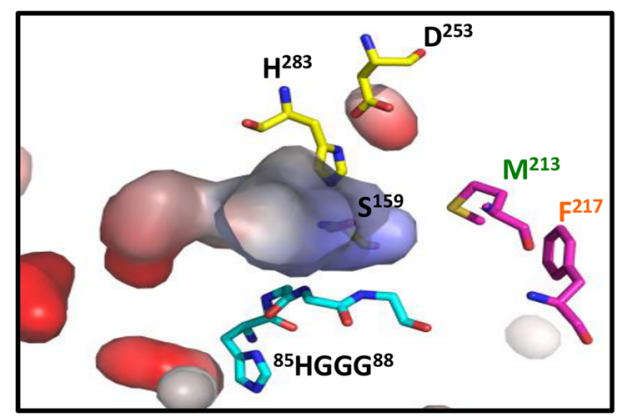

C

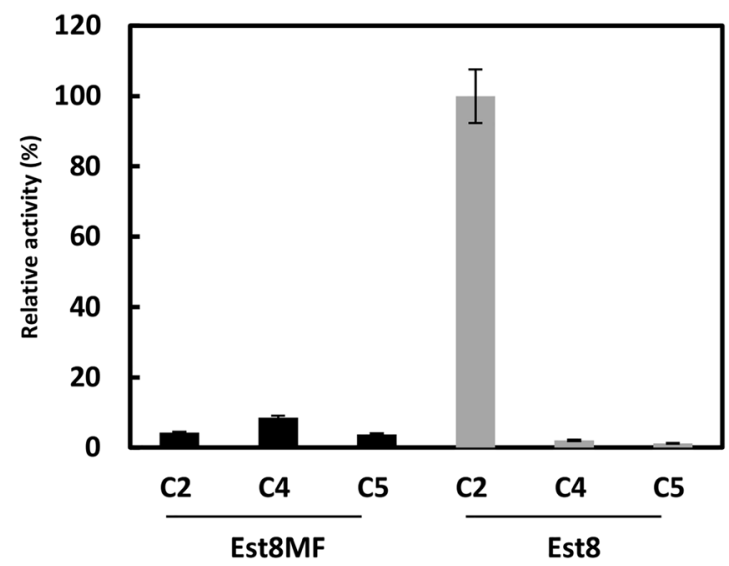

e

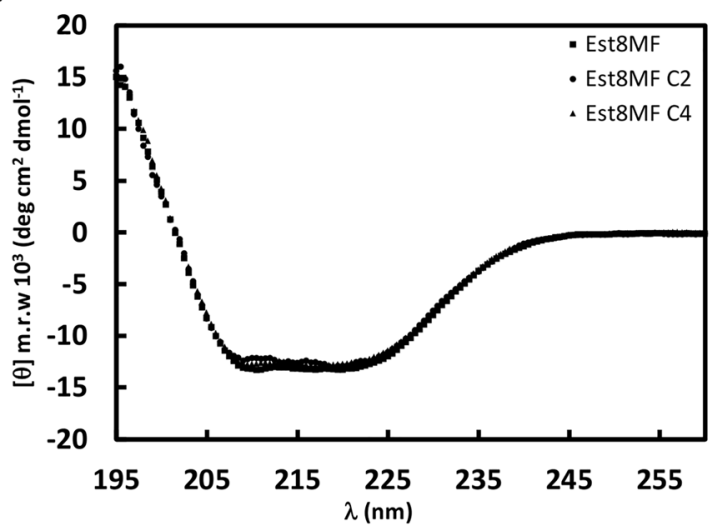

Fig. 6 Protein modeling and functional characteristics of Est8MF. a Est8 active site showing the residues $\mathrm{Met}^{213}$ and $\mathrm{Phe}^{217}$ that block the substrate channel. b Model of the opened channel in Est8MF. $\mathbf{c}$ Enzymatic activity of Est8MF compared to the wild type in presence of $p$-nitrophenyl acetate $\left(\mathrm{C}_{2}\right), p$-nitrophenyl butyrate $\left(\mathrm{C}_{4}\right)$, and $p$-nitrophenyl valerate $\left(\mathrm{C}_{5}\right), \mathbf{d}$ Circular dichroism spectra comparison between Est8 and Est8MF in

Finally, the results presented here show that Est 8 is a new esterase isolated from metagenomic sources that present different characteristics when compared to orthologues previously described, including the two enzymes originated from the same habitat. Indeed, despite the fact that the enzyme did not show high thermal stability, it presented the highest activity against b

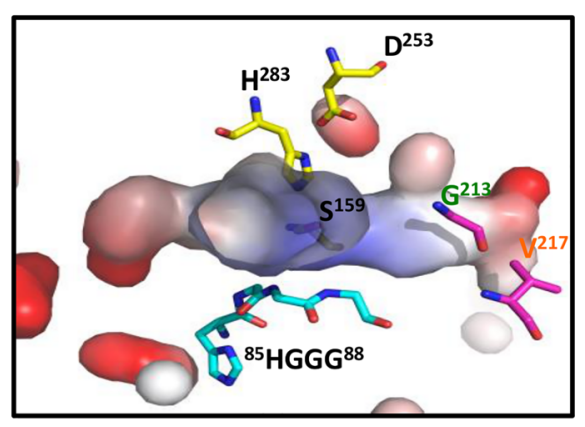

d

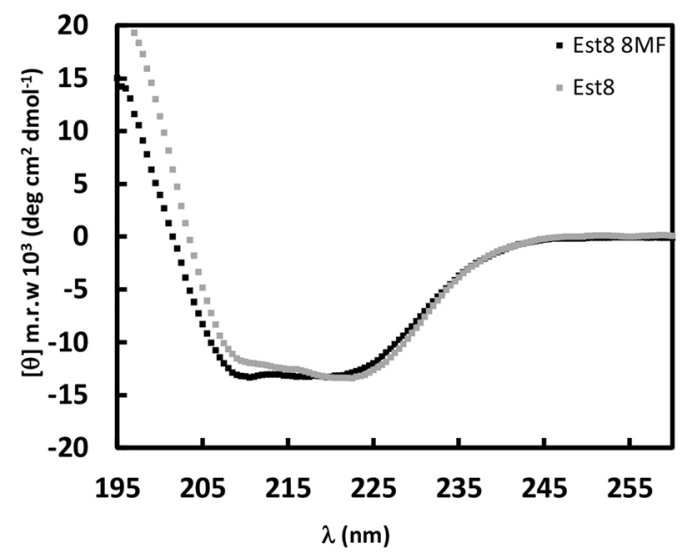

f

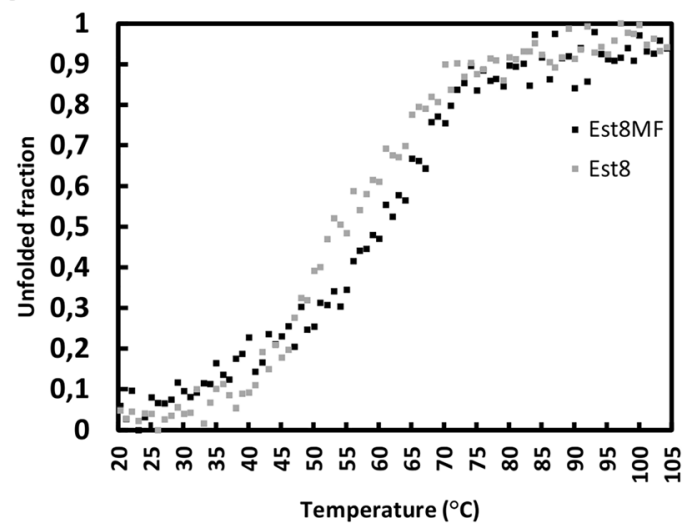

Tris- $\mathrm{HCl} \mathrm{pH}$ 8.0. e Circular dichroism spectra of $5.5 \mu \mathrm{mol}$ Est8MF in presence and absence of substrates $\left[11 \mu \mathrm{mol}\right.$ of $p$-nitrophenyl acetate $\left(\mathrm{C}_{2}\right)$ or $p$-nitrophenyl butyrate $\left.\left(\mathrm{C}_{4}\right)\right]$. The measurement was performed after 30-min incubation with the substrate at room temperature. f Thermal denaturation comparison between Est8 and Est8MF in $\mathrm{pH} 8.0$

substrates of short chains, which could be explored for future applications such as production of milk fatty acid production.

Acknowledgements We are grateful for the Diamond Light Source for the provision of synchrotron radiation facilities, and we would like to thank the beamline managers for the assistance in using beamline I02 
for data collection. We thank the infrastructure offered by the São Paulo State University (UNESP), Jaboticabal Campus, Brazil; the National Laboratory of Biosciences (LNBio), Campinas, Brazil; and the Department of Biochemistry, University of Cambridge.

\section{Compliance with Ethical Standards}

Funding This study was supported by São Paulo State Research Foundation (FAPESP), grant numbers 2011/09136-7 (PhD fellowship) and 2012/20490-0 (Research Internalships Abroad (BEPE)).

Conflict of interest The authors declare that they have no conflict of interest.

Ethical approval This article does not contain any studies with human participants performed by any of the authors.

\section{References}

Angkawidjaja C, Koga Y, Takano K, Kanaya S (2012) Structure and stability of a thermostable carboxylesterase from the thermoacidophilic archaeon Sulfolobus tokodaii. FEBS J 279: 3071-3084

Arpigny JL, Jaeger K-E (1999) Bacterial lipolytic enzymes: classification and properties. Biochem J 343:177-183

Bornscheuer UT (2002) Microbial carboxyl esterases: classification, properties and application in biocatalysis. FEMS Microbiol Rev 26:73-81

Byun J-S, Rhee J-K, Kim ND, Yoon J, Kim D-U, Koh E, Oh J-W, Cho HS (2007) Crystal structure of hyperthermophilic esterase EstE1 and the relationship between its dimerization and thermostability properties. BMC Struct Biol 7:47-51

Chahinian H, Ali YB, Abousalham A, Petry S, Mandrich L, Manco G, Canaan S, Sarda L (2005) Substrate specificity and kinetic properties of enzymes belonging to the hormone-sensitive lipase family: comparison with non-lipolytic and lipolytic carboxylesterases. Biochim Biophys Acta 1738:29-36

Choi Y-J, Lee BH (2001) Culture conditions for the production of esterase from Lactobacillus casei CL96. Bioprocess Biosyst Eng 24:59-63

Delano WL (2010) The PyMOL molecular graphics system. Schrödinger LLC, New York

Emsley P, Cowtan K (2004) Coot: model-building tools for molecular graphics. Acta Crystallogr D Biol Crystallogr International Union of Crystallography 60:2126-2132

Giuliani S, Piana C, Setti L, Hochkoeppler A, Pifferi PG, Williamson G, Faulds CB (2001) Synthesis of pentylferulate by a feruloyl esterase from Aspergillus niger using water-in-oil microemulsions. Biotechnol Lett 23:325-330

Hotta Y, Ezaki S, Atomi H, Imanaka T (2002) Extremely stable and versatile carboxylesterase from a hyperthermophilic archaeon. Appl Environ Microbiol 68:3925-3931

Jaeger K, Reetz MT (1998) Microbial lipases form versatile tools for biotechnology. Trends Biotechnol 16:396-403

Jaeger K-E, Dijkstra BW, Reetz MT (1999) Bacterial biocatalysts: molecular biology, three-dimensional structures, and biotechnological applications of lipases. Annu Rev Microbiol 53:315-351

Jeon JH, Lee HS, Kim JT, Kim S-J, Choi SH, Kang SG, Lee JH (2012) Identification of a new subfamily of salt-tolerant esterases from a metagenomic library of tidal flat sediment. Appl Microbiol Biotechnol 93:623-631

Jin P, Pei X, Du P, Yin X, Xiong X, Wu H, Zhou X, Wang Q (2012) Overexpression and characterization of a new organic solvent- tolerant esterase derived from soil metagenomic DNA. Bioresour Technol 116:234-240

JunGang L, KeGui Z, WenJun H (2010) Cloning and biochemical characterization of a novel lipolytic gene from activated sludge metagenome, and its gene product. Microb Cell Factories 9:83-87

Kabsch W (2010) Xds Acta Crystallogr D Biol Crystallogr 66:125-132

Kim E-Y, Oh K-H, Lee M-H, Kang C-H, Oh T-K, Yoon J-H (2009) Novel cold-adapted alkaline lipase from an intertidal flat metagenome and proposal for a new family of bacterial lipases. Appl Environ Microbiol 75:257-260

Kontkanen H, Tenkanen M, Fagerström R, Reinikainen T (2004) Characterisation of steryl esterase activities in commercial lipase preparations. J Biotech 108:51-59

Lee M-H, Lee C-H, Oh T-K, Song JK, Yoon J-H (2006) Isolation and characterization of a novel lipase from a metagenomic library of tidal flat sediments: evidence for a new family of bacterial lipases. Appl Environ Microbiol 72:7406-7409

Li P-Y, Chen X-L, Ji P, Li C-Y, Wang P, Zhang Y, Xie BB, Qin QL, Zhou BC, Zhang YZ, Zhang XY (2015) Interdomain hydrophobic interactions modulate the thermostability of microbial esterases from the hormone-sensitive lipase family. J Biol Chem 290:11188-11198

Liu L, Suchard MA, Huelsenbeck JP (2012) MrBayes 3.2: efficient Bayesian phylogenetic inference and model choice across a large model space. Syst Biol 61:539-342

Liu Y, Xu H, Yan Q, Yang S, Duan X, Jiang Z (2013) Biochemical characterization of a first fungal esterase from Rhizomucor miehei showing high efficiency of ester synthesis. PLoS One 8:e77856

Lorenz P, Eck J (2005) Metagenomics and industrial applications. Nat Rev 3:510-516

Maester TC, Pereira MR, Machado Sierra EG, Balan A, de Macedo Lemos EG (2016) Characterization of EST3: a metagenomicderived esterase with suitable properties for biotechnological applications. Appl Microbiol Biotechnol 13:5815-5827

Manco G, Mandrich L, Rossi M (2001) Residues at the active site of the esterase 2 from Alicyclobacillus acidocaldarius involved in substrate specificity and catalytic activity at high temperature. J Biol Chem 276:37482-37490

Mandrich L, Merone L, Pezzullo M, Cipolla L, Nicotra F, Rossi M (2005) Role of the $\mathrm{N}$ terminus in enzyme activity, stability and specificity in thermophilic esterases belonging to the HSL family. J Mol Biol 345: 501-512

Murshudov GN, Skubák P, Lebedev AA, Pannu NS, Steiner RA, Nicholls RA, Winn MD, Long F, Vagin AA (2011) REFMAC 5 for the refinement of macromolecular crystal structures research papers. Acta Crystallogr D Biol Crystallogr D67:355-367

Nam KH, Kim M-Y, Kim S-J, Priyadarshi A, Kwon ST, Koo BS, Yoon SH, Hwang KY (2009) Structural and functional analysis of a novel hormone-sensitive lipase from a metagenome library. Proteins 74 : $1036-1040$

Nardini M, Dijkstra BW (1999) $\alpha / \beta$ hydrolase fold enzymes: the family keeps growing. Curr Opnion Struct Biol 9:732-737

Ngo TD, Ryu BH, Ju H, Jang E, Park K, Kim KK, Kim TD (2013) Structural and functional analyses of a bacterial homologue of hormone-sensitive lipase from a metagenomic library. Acta Crystallogr D Biol Crystallogr 69:1726-1737

Ohara K, Unno H, Oshima Y, Hosoya M, Fujino N, Hirooka K, Takahashi S, Yamashita S, Kasunoki M, Nakayama T (2014) Structural insights into the low $\mathrm{pH}$ adaptation of a unique carboxylesterase from Ferroplasma: altering the $\mathrm{pH}$ optima of two carboxylesterases. J Biol Chem 289:24499-24510

Ollis DL, Cheah E, Cyglerl M, Dijkstra B, Frolow F, Franken SM, Harel M, Remington J, Silman I, Schrag J, Sussman JL, Verschueren KHG, Goldman A (1992) The $\alpha / \beta$ hydrolase fold. Protein Eng 5: 197-211

Paixão DAA, Dimitrov MR, Pereira RM, Accorsini FR, Vidotti MB, Lemos EGL (2010) Molecular analysis of the bacterial diversity in 
a specialized consortium for diesel oil. Rev Bras Ciências Solo 34: 773-781

Palm GJ, Fernández-Álvaro E, Bogdanović X, Bartsch S, Sczodrok J, Singh RK, Bottcher D, Atomi H, Bornscheuer UT, Hinrichs W (2011) The crystal structure of an esterase from the hyperthermophilic microorganism Pyrobaculum calidifontis VA1 explains its enantioselectivity. Appl Microbiol Biotechnol 91:1061-1072

Peng Q, Wang X, Shang M, Huang J, Guan G, Li Y, Shi B (2014) Isolation of a novel alkaline-stable lipase from a metagenomic library and its specific application for milkfat flavor production. Microb Cell Factories 13:1-9

Peränen J, Rikkonen M, Hyvonen M, Kaarianen L (1996) T7 vectors with a modified T7lac promoter for expression of proteins in Escherichia coli. Anal Biochem 373:371-373

Pereira MR, Mercaldi GF, Maester TC, Balan A, Lemos EGDM (2015) Est16, a new esterase isolated from a metagenomic library of a microbial consortium specializing in diesel oil degradation. PLoS One 10:e133723

Quax WJ, Brokhuizen C (1994) Development of a new Bacillus carboxyl esterase for use in the resolution of chiral drugs. Appl Microbiol Biotechnol 41:425-431

Rao L, Xue Y, Zheng Y, Lu JR, Ma Y (2013) A novel alkaliphilic Bacillus esterase belongs to the 13(th) bacterial lipolytic enzyme family. PLoS One 8:e60645

Rhee J, Ahn D, Kim Y, Oh J (2005) New thermophilic and thermostable esterase with sequence similarity to the hormone-sensitive lipase family, cloned from a metagenomic library. Appl Environ Microbiol 71:817-825
Ronquist F, Teslenko M, van der Mark P, Ayres DL, Darling A, Höhna S, Larget B, Liu L, Suchard MA, Huelsenbeck JP (2012) Mr-Bayes 3.2: efficient Bayesian phylogenetic influence and model choice across a large model space. Syst Biol 61:539-542

Tamura K, Stecher G, Peterson D, Filipski A, Kumar S (2013) MEGA6: Molecular Evolutionary Genetics Analysis version 6.0. Mol Biol Evol 30:2725-2729

Thompson JD, Higgins DG, Gibson TJ (1994) ClustalW: improving the sensitivity of progressive multiple sequence alignment through sequence weighting, position-specific gap penalties and weight matrix choice. Nucleic Acids Res 22:4673-4680

Wei Y, Contreras JA, Sheffield P, Osterlund T, Derewenda U, Kneusel RE, Matern U, Holm C, Derewenda ZS (1999) Crystal structure of brefeldin A esterase, a bacterial homolog of the mammalian hormone-sensitive lipase. Nat Struct Biol 6:340-345

Winn MD, Ballard CC, Cowtan KD, Dodson EJ, Emsley P, Evans PR, Keegan RM, Krissinel EB, Leslie AG, McCoy A, McNicholas SJ, Murshudov GN, Pannu NS, Potterton EA, Powell HR, Read RJ, Vagin A, Wilson KS (2011) Overview of the CCP4 suite and current developments. Acta Crystallogr D Biol Crystallogr International Union of Crystallography 67:235-242

Yang S, Qin Z, Duan X, Yan Q, Jiang Z (2015) Structural insights into the substrate specificity of two esterases from the thermophilic Rhizomucor miehei. J of Lipid Res 56:1616-1624

Zhu X, Larsen NA, Basran A, Bruce NC, Wilson IA (2003) Observation of an arsenic adduct in an acetyl esterase crystal structure. J Biol Chem 278:2008-2014 